\title{
DỨBin
}

Technological University Dublin

ARROW@TU Dublin

\section{Dielectric Study of Liquid Crystals with Large Electroclinic Effect}

O. E. Panarina

Trinity College Dublin, Ireland

Yuri Panarin

Technological University Dublin, yuri.panarin@tudublin.ie

J. K. Vij

Trinity College Dublin, Ireland, jvjj@tcd.ie

Follow this and additional works at: https://arrow.tudublin.ie/engscheleart2

Part of the Electrical and Computer Engineering Commons

\section{Recommended Citation}

Panarin, Yu. P. et al. (2015). Dielectric study of liquid crystals with large electroclinic effect. Molecular Crystals and Liquid Crystals, vol. 610, pp. 193-200. Dol:10.1080/15421406.2015.1025650

This Article is brought to you for free and open access by the School of Electrical and Electronic Engineering at ARROW@TU Dublin. It has been accepted for inclusion in Articles by an authorized administrator of ARROW@TU Dublin. For more information, please contact arrow.admin@tudublin.ie, aisling.coyne@tudublin.ie, gerard.connolly@tudublin.ie.

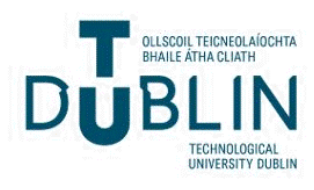




\title{
Dielectric Study of Nematic LC Built with Bent-core Molecules
}

\author{
S. SREENILAYAM,${ }^{1}$ YU. PANARIN,${ }^{1,2, *}$ AND J. K. VIJ ${ }^{1}$ \\ ${ }^{1}$ Advanced Materials Laboratory, Department of Electronic and Electrical \\ Engineering, Trinity College, University of Dublin, Dublin, Ireland \\ ${ }^{2}$ School of Electrical \& Electronic Engineering, Dublin Institute of Technology, \\ Dublin, Ireland
}

\begin{abstract}
Here we report results of the study of bent-core $(B C)$ cybotactic nematic LC by dielectric spectroscopy and electro-optic measurements. In the absence of electric field, this material is uniaxial and exhibits only one relaxation process corresponding to the fluctuations of the polar clusters. The application of the external electric field induces biaxiality and the second relaxation process appears in the dielectric spectra. This is assigned to the collective mode. Possible models for cluster transformation under electric field are discussed.
\end{abstract}

Keywords biaxial liquid crystal; bent-core; dielectric relaxation; electro-optic effects

\section{Introduction}

Since Freiser predicted the existence of biaxiality in Liquid Crystals in 1970 [1], the study of biaxiality has attracted enormous interested due to a potential for practical application of a new mode in the display industry. The existence of biaxiality was experimentally observed in different LC systems such as: the lyotropic nematic phase; liquid crystalline polymers; organosiloxane tetrapodes; and some other complex systems. The possibility of the existence of a biaxial nematic phase in biaxial parallelepiped "or bricklike" shaped molecules [2-4] and in bent-core (BC) systems [5-7] has been supported by numerous theoretical and computational studies. It has proven extremely difficult to unambigously find repeatable value of biaxiality in the nematic phase. Though it has been reported to exist in a low molar mass smectic BC systems but controversy exists as to whether it is intrinsic biaxiality or is caused by surfaces. [8-10]. From a practical point of view, the biaxial nematic phase has a secondary director $\boldsymbol{m}$ perpendicular to the primary director $\boldsymbol{n}$; the latter is always prevalent in the nematic phase. The switching of the secondary director compared to the primary one can be one to two orders of magnitude faster. Therefore, such biaxial nematics with improved response offer significant advantages over the conventional nematics in applications for fast displays and photonic devices. This has spurred activity not only in experiments but also in analytical theory augmented by the computational studies of the biaxial nematic phase.

\footnotetext{
*Address correspondence to Yu. Panarin, School of Electrical \& Electronic Engineering, Dublin Institute of Technology, Kevin Street, Dublin, 8, Ireland. E-mail: yuri.panarin@ dit.ie

Color versions of one or more of the figures in the article can be found online at www.tandfonline.com/gmcl.
} 
Nevertheless, it is quite clear that the LC molecules on a microscopic level are biaxial and the macroscopic biaxiality can be induced by electric field [11]. The electro-optical switching can be effected by the electrically induced biaxiality and this does need application of high electric field [11]. On the other hand it is also known that some smectic LCs can have large macroscopic biaxiality with much lower electric field but there are other disadvantages [12-14].

In this paper we present results of the study of the nematic phase exhibited by BC molecules using dielectric spectroscopy and electro-optic measurements.

\section{Experimental}

The LC sample under study, BCN48 is a 5-ring BC material, which shows only nematic phase. The molecular structure and the phase transitions temperatures are given in Fig. 1.

Optical studies in the temperature range of the nematic phase suggest the appearance of a so-called "cybotactic" nematic phase $N_{C}$ with smectic-like biaxial clusters [15-21]. In $\mathrm{BC}$ systems, a deviation from the calamitic shape and a large transverse dipole moment lead to unusually strong intermolecular interactions which give rise to the formation of polar domains or clusters.

The effect of electric field on the textures is studied in a $4 \mu \mathrm{m}$ cell with foil spacers as electrodes. A square-wave field $100 \mathrm{~Hz}$ is applied across the electrodes in the plane of a glass plate. The cell was placed between the crossed polarizers with an angle of $45^{\circ}$ between the electric field direction and the polarizer axis. Initially for a rather small electric field, no significant effect is observed and the LC remains optically uniaxial. On applying a relatively large electric field, the collective alignment of domains occurs and this leads to a macroscopically biaxial ordering [18]. On removal of the electric field, the domains get again randomized, with a corresponding drop in the biaxial order parameter. This effect was studied in [12] for another sample. However, it is still not clear whether such a nematic LC consists of distinguishable clusters of a lower symmetry or are the regions correlated with a short-range order.

Dielectric spectroscopy is useful complementary technique to characterize different phases and find structures of LC phases such as AFLCs [22], de Vries [23, 24], TGBA [25], etc. Here we use it to distinguish the polar phases from the non-polar ones. The latter are not active in the dielectric spectra.

Both planar and homeotropic cells containing the LC sample for dielectric measurements were prepared. The low resistance $(\sim 20 \Omega / \mathrm{cm})$ indium tin oxide (ITO) glass substrates were used for the dielectric study to avoid the parasitic peak in the dielectric loss spectra due to the contribution of ITO or at least to shift this peak to a higher frequency range $\sim 10 \mathrm{MHz}$. Dielectric measurements on planar cells of two different thicknesses:

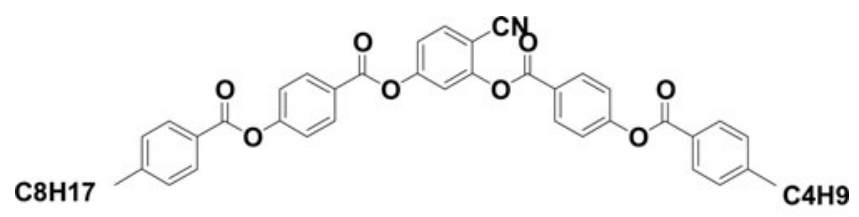

$\mathrm{Cr} 62^{\circ} \mathrm{C} \mathrm{N} 96^{\circ} \mathrm{C}$ Iso

Figure 1. The molecular structure and the phase transition temperatures of the studied sample. 

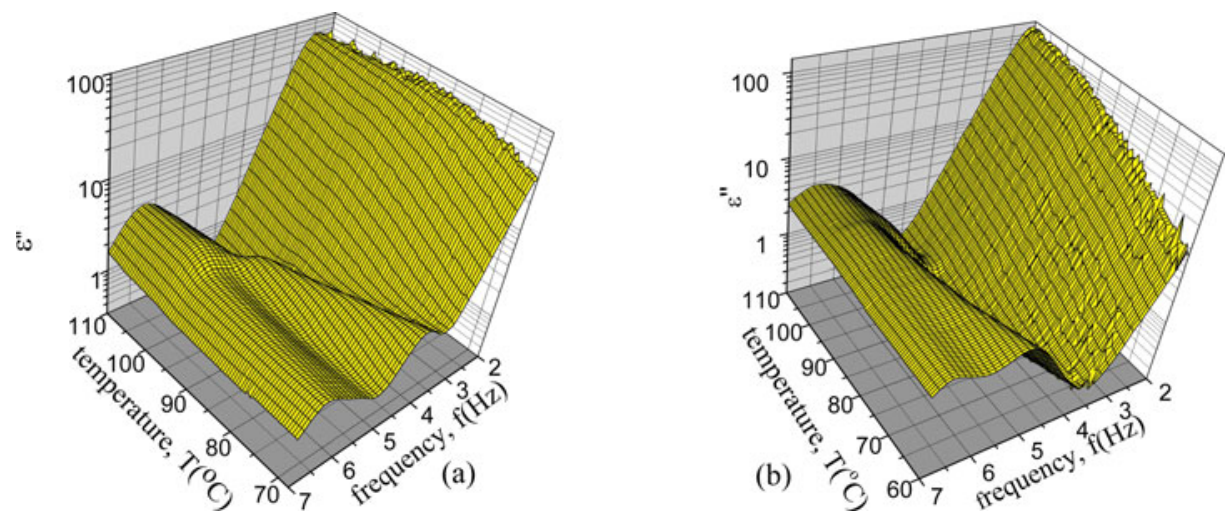

Figure 2. Dielectric loss spectra of (a) homeotropic cell (cell thickness, $d=9.7 \mu \mathrm{m}$ ) and (b) planar cell (cell thickness, $\mathrm{d}=6.1 \mu \mathrm{m}$ ) filled with the LC- BC48 LC material.

$6.1 \mu \mathrm{m}$ and $3.8 \mu \mathrm{m}$ were made to study the effect of the cell thickness on dielectric spectra. The capacitance of the empty cell was determined prior to its filling with the LC sample. The measurement was carried out under cooling over a temperature range $100^{\circ} \mathrm{C}$ to $30^{\circ} \mathrm{C}$ with a step of $1^{\circ} \mathrm{C}$. The temperature of the sample was stabilized within $0.05^{\circ} \mathrm{C}$. The measuring $\mathrm{AC}$ voltage was varied from $0.1 \mathrm{~V}$ to a maximal available $3 \mathrm{~V}$ to find the effect of applied voltage on the results of dielectric spectroscopy. The dielectric spectra were found independent of the applied voltage and hence an applied voltage of $1 \mathrm{~V}$ was chosen for reducing the effect of noise on the spectra.

Figure 2 shows the temperature and frequency dependent dielectric loss spectra measured in (a) homeotropic, and (b) homogeneous cells.

Both planar and homeotropic cell configurations show similar dielectric spectra. In isotropic phase, there is only one temperature independent peak which is due to the finite resistance of the ITO electrodes in series with the cell capacitance and is centered at a frequency of $\sim 3 \mathrm{MHz}$. On cooling the cell to the nematic phase of the LC material, a second temperature dependent peak appears on the lower frequency side of the first one.

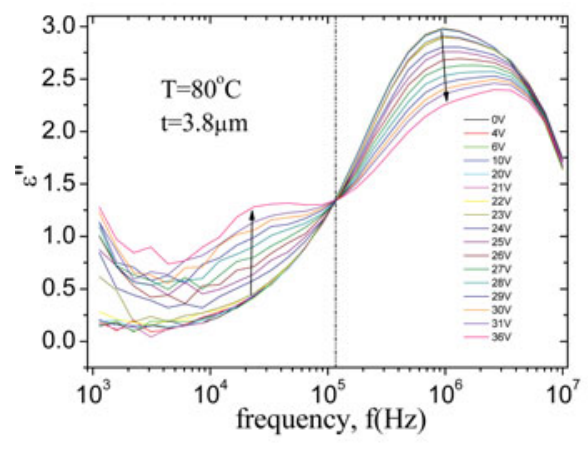

(a)

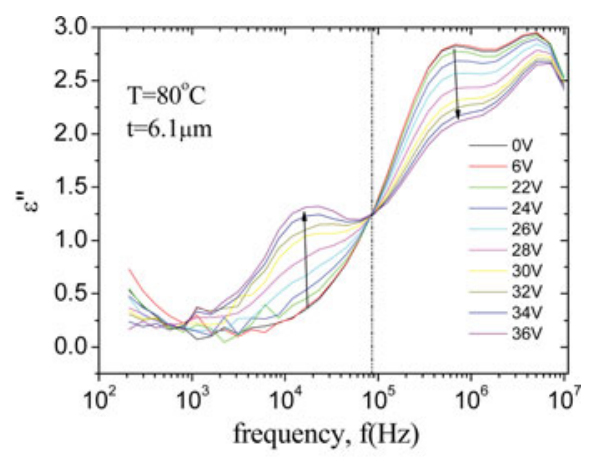

(b)

Figure 3. Dielectric loss spectra of planar cells: (a) $\mathrm{d}=3.8 \mu \mathrm{m}$ and (b) $6.1 \mu \mathrm{m}$ measured at $\mathrm{T}=$ $80^{\circ} \mathrm{C}$. 


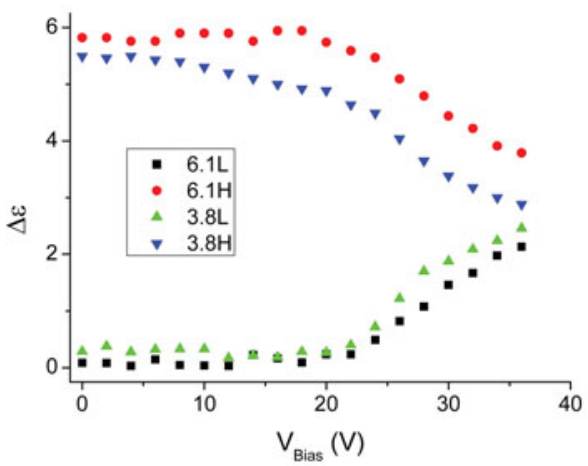

(a)

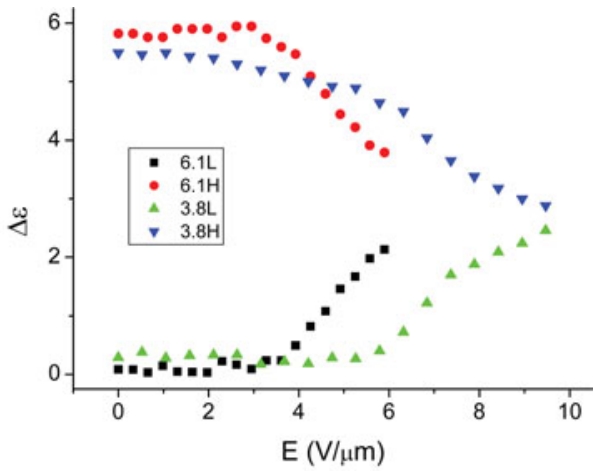

(b)

Figure 4. The dependence of dielectric strength of the two relaxation processes on (a) bias voltage and (b) electric field.

This peak is related to the relaxation process of the polar clusters [12] around the nematic director in a planar cell and is normal to the director in a homeotropic cell.

We have studied the effect of bias electric field in the planar cells of two thicknesses: $3.8 \mu \mathrm{m}$ and $6.1 \mu \mathrm{m}$. Dependence of the dielectric spectra on bias voltage for both cells is shown in Fig. 3.

The dependencies of the dielectric spectra on bias voltage in both cells are found to be similar: at low electric field there is only one relaxation peak (excluding the parasitic peak arising from the bias voltage (higher than $\sim 20 \mathrm{~V}$ ), the second lower frequency relaxation peak shows up. On further increasing the bias, the dielectric strength of this process gradually grows while the dielectric strength of the higher frequency process decreases. Figure 4 shows the dependence of dielectric strength of both processes on (a) bias voltage and (b) electric field and these results are deduced from Fig. 3.

The threshold voltage of $20 \mathrm{~V}$ corresponds to an electric field of $3-5 \mathrm{~V} / \mu \mathrm{m}$ at which the optical (macroscopic) biaxiality appears in the optical homeotropic cell. Therefore one may conclude that the lower frequency process is due to the relaxation of electrically aligned volume of clusters, while the higher relaxation process is due to the relaxation of the individual clusters.

It is interesting to note that the relaxation frequencies of both processes are almost independent of the bias voltage and the cell thickness. This means that the dimensions of clusters are also independent of the bias and cell thickness and this result is in agreement with the theoretical and Monte-Carlo simulations.

\section{Funding}

We thank the Science Foundation of Ireland for the grant 13/US/I2866 under Ireland-US co-operative research program.

\section{References}

[1] Freiser, M. J. (1970). Phys. Rev. Lett., 24, 1041.

[2] Wensink, H. H., Vroege, G. J., and Lekkerkerker, H. N. W. (2002). Phys. Rev. E, 66, 041704.

[3] Teixeira, P. I. C., Osipov, M. A., and Luckhurst, G. R. (2006). Phys. Rev. E, 73, 061708. 
[4] Allender D., and Longa, L. (2008). Phys. Rev. E, 78, 011704.

[5] Bates M. A., and Luckhurst, G. R. (2005). Phys. Rev. E, 72, 051702.

[6] Peláez J., and Wilson, M. R. (2006). Phys. Rev. Lett., 97, 267801.

[7] Vanakaras A. G. and. Photinos, D. J (2008). J. Chem. Phys., 128, 154512.

[8] Madsen, L. A., Dingemans, T. J., Nakata, M., and Samulski, E. T. (2004). Phys. Rev. Lett., 92, 145505.

[9] Acharya, B. R., Primark, A., and Kumar, S. (2004). Phys. Rev. Lett., 92, 145506.

[10] Prasad, V.,. Kang, S.-W, Suresh, K. A., Joshi, L., Wang, Q., and Kumar, S. (2005). J. Am. Chem. Soc., 127, 17224.

[11] Nagaraj, M., Panarin, Yu. P., Manna, U., Vij, J. K., Keith, C., and Tschierske, C. (2010). Appl. Phys. Lett., 96, 011106.

[12] Nagaraj, M., Panarin, Yu. P., Manna, U., Vij, J. K., Keith, C., and Tschierske, C. (2010). Appl. Phys. Lett., 97, 213505.

[13] Panarin, Yu. P., Nagaraj, M., Vij, J. K., Keith C., and Tschierske C., (2010). Euro. Phys. Lett. 92, 26002.

[14] Panarin, Yu. P., Nagaraj, M., Sreenilayam, S., Vij, J. K., Lehmann, A., and Tschierske, C. (2011). Phys. Rev. Lett. 107, 247801.

[15] Stojadinovic, S., Adorjan, A., Sprunt, Sawade, S. H., and Jakli, A. (2002). Phys. Rev. E, 66, 060701.

[16] Liao, G., Stojadinovic, S., Pelzl, G., Weissflog, W., Sprunt, S., and Jakli, A. (2005). Phys. Rev. $E, 72,021710$.

[17] Kovalenko, L., Schroder, M. W., Reddy, R. A., Diele, S., Pelzl, G., and Weissflog, W. (2005). Liq. Cryst., 32, 857.

[18] Stannarius, R., Eremin, A., Tamba, M.-G., Pelzl, G., and Weissflog, W. (2007). Phys. Rev. E, $76,061704$.

[19] Lee, J. H., Lim, T. K., Kim, W. T., and Jin, J. I. (2007). J. Appl. Phys., 101, 034105.

[20] Görtz, V., Southern, C., Roberts, N. W., Gleeson, H. F., and Goodby, J. W. (2009). Soft Matter, $5,463$.

[21] Francescangeli, O., Stanic, V., Torgova, S. I., Strigazzi, A., Scaramuzza, N., Ferrero, C., Dolbnya, I. P., Weiss, T. M., Berardi, R., Muccioli, L., Orlandi, S., and Zannoni, C. (2009). Adv. Funct. Mater. 19, 2592.

[22] Panarin, Yu., Xu, H., Mac Lughadha, S. T., Vij, J. K., Seed, A. J., Hird, M., Goodby, J. W., (1995). J. Phys.: Condens. Mater, 7, L351.

[23] Panarina, O.E., Panarin, Yu., Antonelli, F., Vij, J.K., Reihmann, M., Galli, G. (2006). J. Matter. Chem., 16, 842 .

[24] Manna, U., Song, J.-K., Panarin, Yu., Fukuda, A., Vij, J.K. (2006). Phys. Rev. E, 77, 041707.

[25] Xu, H.. Panarin, Yu., Vij, J.K., Seed, A., Hird, M., Goodby J.W., (1995). J. Phys.: Condens. Mater., 7, 7443. 